\title{
THE BATTLE FOR RUSSIA'S BRAINS
}

The Russian Academy of Sciences has resisted pressure from czarists and communists. Can it thwart the reforms planned by Putin's government? Quirin Schiermeier reports.

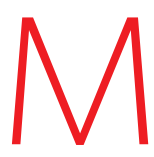

uscovites have a complex relationship with the bold architecture they call the "building with the golden brain". The widely visible tower near Gagarin Square in the southwest of the Russian capital, topped by a futuristic chaos of glistening copper pipes and air shafts, is the modern headquarters of the Russian Academy of Sciences, founded in 1724 by Peter the Great. For many it symbolizes the pride and glory of science in a nation that has traditionally held researchers, inventors and explorers in high esteem. But for others the overly ornate superstructure can all too easily be seen as emblematic of the arrogance of an isolated and ageing academic élite that has little to offer Russia as it moves towards a knowledge-driven modern society.

The feeling that the academy, which employs some 50,000 scientists across 418 research institutes, is in dire need of reform is widespread even among scientists affiliated with the institution. Critics say that it is controlled by an old guard of 1,250 academicians raised under a Soviet culture who cling to their privileges and rituals. The academy, they say, has become a comfortable refuge for tens of thousands of unproductive 'shadow researchers' who await their pensions while producing little or no science of any merit. In the absence of proper quality control and competition, pessimists warn, Russia will risk falling further behind up-andcoming science nations in Asia, and could even struggle to maintain its status as a second-rate science nation. The response from many leading academicians within the academy is that Western-style research with its 'publish or perish' mentality offers a rat race unworthy of the noblesse of true science.

"Ten years ago Russian scientists published ten times more papers in journals such as Nature and Science than Chinese researchers did - now the Chinese have twice as many as we do," says Alexander Sobolev, a geochemist at the academy's Vernadsky Institute of Geochemistry and Analytical Chemistry in Moscow, who is frustrated by the slow pace of reform. "The problem is that the academy just doesn't support a system in which productivity counts. Scientific careers in Russia don't depend on results, and nobody really cares about international expertise. We simply don't provide the right motivation for scientific work."

Motivation understandably waned during the

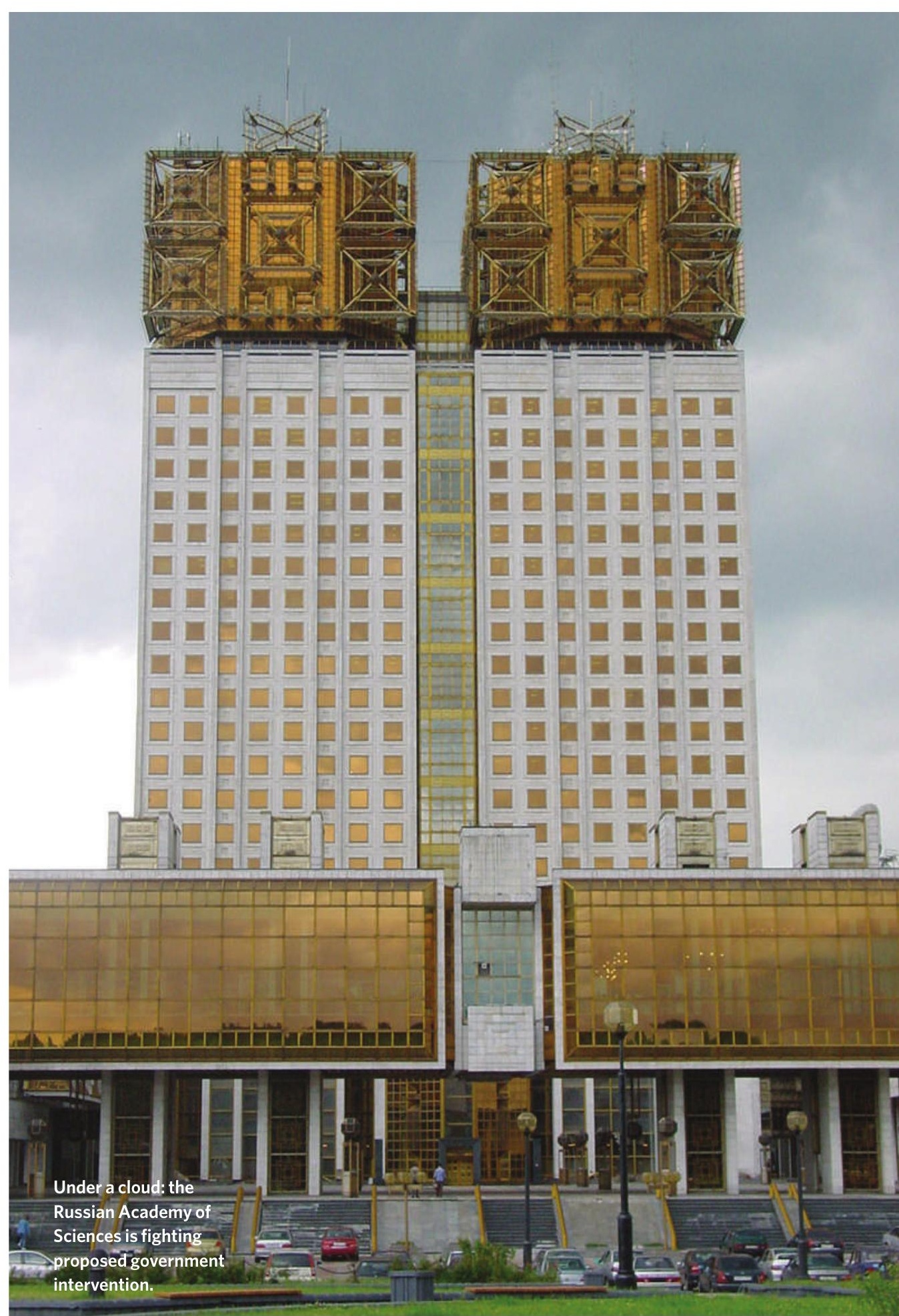


1990s, after the break up of the Soviet Union, when scant scientific salaries forced talented Russian scientists to find second or third jobs outside science, or to leave research altogether. Many more emigrated to research positions abroad. During the hardest years, even top academicians officially earned little more than US $\$ 100$ per month. Without generous support from foreign governments and organizations, such as the Soros Foundation in New York, set up by Hungarian billionaire George Soros, the Soviet Union's scientific heritage might have decayed beyond repair.

During this period of crumbling science budgets and galloping inflation, many were concerned about Russia's nuclear heritage and its emigrating scientists. The nation was living permanently in debt, and could hardly afford to maintain some 4,000 Soviet research organizations. As economist Boris Saltykov, the first minister of science in the post-Soviet government, said in 1992: "In Russia we have too much science." But he, like others after him, struggled to reform the academy.

Against the odds, the number of academy institutes actually rose after 1990, from 330 to 418 today. The number of academicians has also grown, at the expense of other scientific employees, and despite frequent criticisms of inertia and unproductivity. Some wonder if the academy is unreformable - a feature of the Russian landscape as enduring as the Siberian steppes.

The current science minister, Andrei Fursenko, formerly a physicist at the renowned Ioffe Physico-Technical Institute in St Petersburg, is determined to make the academy more accountable. Sources close to the ministry say that long-standing discussions over the reform of the academy are turning into a real power struggle. In January, Fursenko suggested a 'model charter', which the academy's general assembly rejected in March on the grounds that it would give the ministry bureaucratic control over the academy. The academy has proposed its own charter, but a compromise is unlikely, and so the deadlock continues. Whether the academy can resist all attempts at external and internal reform remains to be seen.

\section{Paper trail}

What is the state of Russia's scientific output today? Certainly its publication record remains bleak. "Too many people here call themselves scientists without having published a single paper in the past decade," says Boris Stern, an astrophysicist at the P. N. Lebedev Physics Institute in Moscow. In 2001, Stern received a small grant from the Russian Foundation for Basic Research in Moscow to build up a database of the scientific productivity of Russian scientists and scientific institutes. He regularly

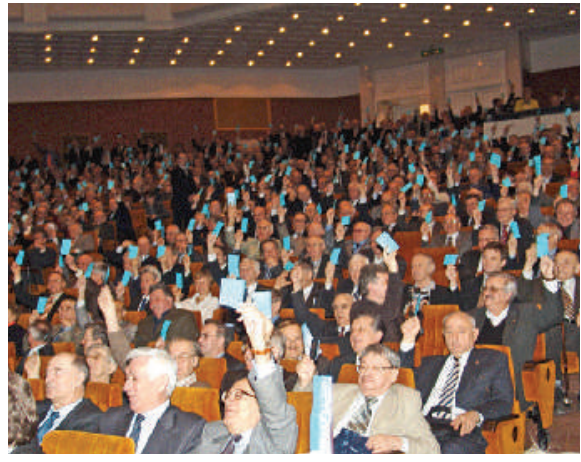

The academy's general assembly voted to oppose a new charter proposed by the government.

updates this 'Who's who in Russian science' with the latest information from Thomson Scientific, a citation service based in Philadelphia, Pennsylvania.

"The problem is that we have a totally biased system for scientific reputation in Russia," says Stern. "The formal administrative hierarchy has nothing to do with informal reputation." For example, Stern's list of the most productive institutes is topped by Lomonosov Moscow State University, which is not an academy institute. And Stern found that fewer than 50,000 Russian scientists - one-eighth of the total workforce - publish at least one paper a year. According to the 2006 World Bank Russian Economic Report, researchers in Poland, India, Brazil and South Korea generate 2-3 times as many papers per person. And patent numbers tell a similar tale: patents produced per capita are 60 times higher in South Korea than Russia.

The low productivity has not escaped the attention of

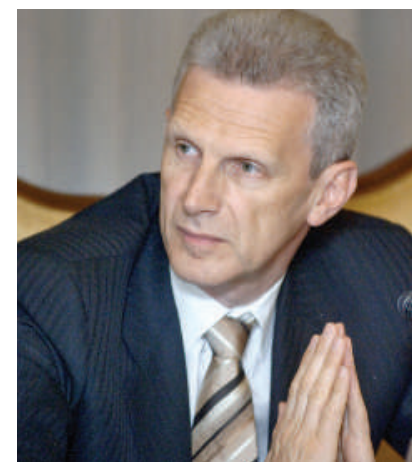

Science minister Andrei Fursenko wants to make the academy more accountable.
The nanotech initiative, which almost matches the $\$ 1.3$ billion per year the academy receives from the government, can be seen as an attempt to develop a new state sector of science outside the academy, says Saltykov. In fear of being passed over, the academy rushed to appoint Mikhail Kovalchuk, a physicist with close ties to Putin and the head of the nanoinitiative, as its 'acting' vice-president for nanotechnology. The move has been criticized as a violation of the academy's statutes, which state that only full members can be elected into leadership positions - Kovalchuk is only a corresponding member.

\section{State control}

Having already threatened the academy's pre-eminence as Russia's main basic-research organization, the government is also starting to encroach on its internal operations, which remarkably survived the communist era intact. Last December, Putin signed the new 'Law on Science and Technology State Policy' which, among other things, modified the legal status of the academy to give the government more control over its operations. The new law includes a provision that allows Putin to approve the elected president of the academy - a requirement that has dismayed some leading academicians.

Alexander Nekipelov, one of the academy's chief vicepresidents, says he thinks it was 'merely a symbolic act.' "I don't think [Putin] can actually disapprove of an academy president who has been properly elected according to our rules," he adds. Still, last November, in anticipation of the new rules, the academy postponed the election of a successor to its current presithe Kremlin. As the government invests in the country's diminished science base - the overall number of researchers has declined by more than 100,000 since 1995 - expectations will rise and so focus new attention on the academy's sagging performance. President Vladimir Putin is determined to give the Russian economy, which leans towards exploitation of the country's abundant oil and gas resources, a more solid industrial base. Science will be a tool on the road to a new economy Putin said in May in a speech to the State Duma, the lower house of the Russian parliament. In July, the Duma dutifully approved a massive \$7-billion investment in nanotechnology over the next five years, which Putin and his advisers think will lessen Russia’s dependence on petrodollars (see Nature 448, 233; 2007). dent, Yuri Osipov, who has reached the age limit of 70. It's not yet clear when a new academy president will be elected - it may be as late as 2008, when the country will also choose a successor to Putin.

Nekipelov does admit to "major disagreements" with the science ministry over the future course and governance of the academy. According to Fursenko's charter, important decisions, such as creating new laboratories or closing existing ones, and on allocation of funds, would be handed over to supervisory committees, in which government representatives would hold the majority. Research money would be given to individual teams on a purely competitive basis rather than as a lump sum to the academy presidium. 


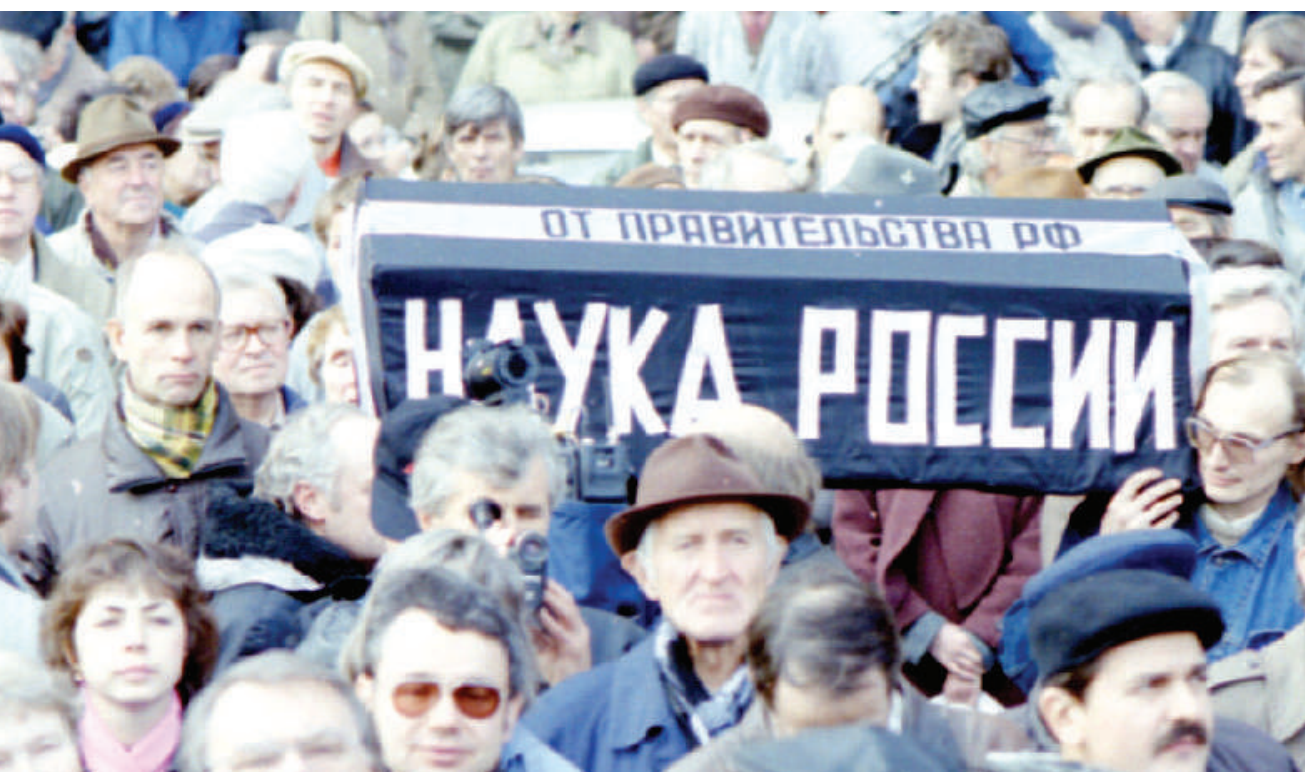

A coffin bearing the words 'Science of Russia' symbolizes scientists' views about funding levels.

The academy leadership, backed by most of the full and corresponding academicians who make up the general assembly, vehemently opposes the new law and subsequent charter. It has prepared its own charter, which is currently being reviewed by the government, in which the academy would remain a self-governed organization, free to allocate funds independently, and with the right to set up, modify or liquidate institutes as it sees fit.

The academy is keen that most of its budget remain as basic institutional funding - as a fixed lump sum. But it has suggested that $20 \%$ of the money it receives from the government in future will be distributed though a 'competitive' interdisciplinary programme. The ministry would like to reduce institutional funding to a minimum, and introduce performance-related funding of projects and individuals, including consideration of scientists' international publication record. Many academicians hate this idea because their low publication rate in international journals would exclude most of them from getting funding under any competitive programme. If competition is to be introduced, they would prefer the programme to be managed 'in-house', using internal expertise to evaluate grants. But the government is unlikely to accept this proposal, and a compromise is currently not in sight.

To outsiders, the academy seems to be fighting a losing battle. The ministry holds the purse strings, and can force through legislation to restructure the academy. Indeed, the government has threatened to block next year's round of promised pay rises to increase pressure on the academicians, says Nekipelov.

Average salaries for academy scientists were to

jump to $\$ 1,200$ per month by 2008 , in exchange for the academy cutting staff by $20 \%$. Two years ago, average monthly salaries were still as low as $\$ 200$; they are now at around $\$ 500$, roughly similar to that of the average industrial worker. To justify even higher salaries, the government wants to impose on the academy a performancerelated system that it hopes will improve the scientific output of its workforce. Future salaries would be composed of a fixed part - the tarif — plus bonuses for measurable scientific achievements.

Nekipelov gets animated when it comes to what he calls 'paying by results'. He disagrees that a simple indicator, such as the number of publications in international journals, can measure researchers' performance, as has been proposed by the science ministry. "People would start working for 'indicators' only,' he says.

"Some people think that our scientists just want to pocket salaries but not work hard, and that there is no such thing as competition in

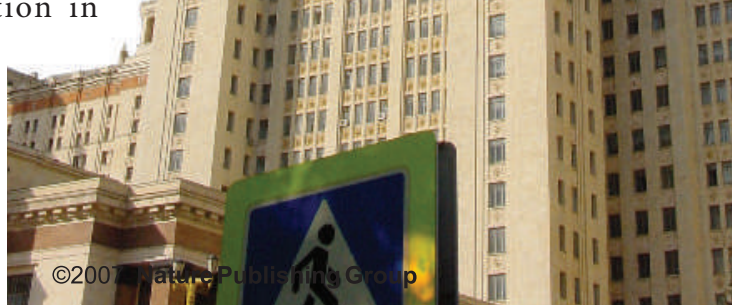

\section{Fresh blood}

our institutes," he says. "That's wrong. The truth is that scientific work as such is a very competitive activity. All academy scientists compete for funds allocated to their institutes, while institutes compete for funds allocated to different fields of science, and so forth."

Nekipelov also disputes the widely held view that most academy researchers are isolated from, and rather indifferent about, international trends in science, and refuse to give talks or write papers in English. "We do have many unofficial relations with colleagues abroad," he says. He is also critical of the influence of international journals and foreign reviewers: "The working language in this country is indeed Russian, scientists will not start speaking English here."

Saltykov is dismayed to hear this: "If that is so, then what we are doing here has nothing to do with international science." Saltykov is in favour of radical reorganization of the academy. With the exception of a few young scientists with ties to the West, he says, the members of the academy continue to live in a Soviet-type economy and state of mind. "They say that science and the market are incompatible, whereas in fact they consider money more important than principles. And they keep demanding budget money, but would like to remain totally unaccountable."

Only about one-quarter of academy scientists are truly competitive, hard-working researchers, says Saltykov. He cites an unpublished review of 1,330 academy researchers done in 2005 by sociologist Sergei Belanovsky on behalf of the Moscow-based Centre for Strategic Research, a think-tank close to the ministry of economics. The study showed that almost half of the academy's scientific workforce was unproductive dead weight. Nekipelov accepts that something needs to be done: "We do have quite a strong potential," he says, "but it's true that we need more young people, and that we need to free ourselves from some of the elders who don't do much science any more."

"People here are very experienced in the art of imi-

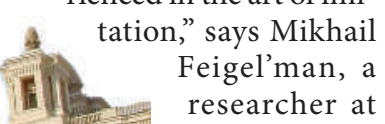
Feigel'man, a researcher at

Outside the academy: Moscow State University is one of Russia's most productive institutes. 
